DOI: $10.17951 / \operatorname{lrp} .2016 .35 .1 .157$

\author{
Barbara Skatbania \\ TERESA LEWANDOWSKA-KIDOŃ
}

Wyższa Szkoła Pedagogiczna im. Janusza Korczaka w Warszawie

\title{
POMOC PSYCHOLOGICZNO-PEDAGOGICZNA W SZKOLE - MIĘDZY RUTYNĄ A REFLEKSYJNĄ PRAKTYKĄ
}

\begin{abstract}
Abstrakt: Celem artykułu jest podkreślenie refleksyjności jako ważnego elementu działania pedagogicznego, jak również potrzeby kształcenia refleksyjnych praktyków, zgodnie z zapisami Rozporządzenia Ministra Nauki i Szkolnictwa Wyższego z 17 stycznia 2012 r. w sprawie standardów kształcenia przygotowującego do wykonywania zawodu nauczyciela. Rozważania tematyczne dotyczą procesu edukacji, a szczególnie są ukierunkowane na obszar pomocy psychologiczno-pedagogicznej z uwagi na dość marginalne jego traktowanie w odniesieniu do licznych i wielozakresowych analiz funkcjonowania szkoły, zwłaszcza w zakresie jej działalności dydaktycznej.
\end{abstract}

Słowa kluczowe: pomoc psychologiczno-pedagogiczna, refleksyjny praktyk, kompetencje nauczycieli

\section{WPROWADZENIE}

Kategoria pomoc zawiera dwa kluczowe słowa: wspomaganie i wspieranie, które Irena Obuchowska (1997) włączyła do szerokiego pojęcia „wychowanie”. Zdaniem Bogusława Śliwerskiego, „refleksji pedagogicznej od początku towarzyszy przeświadczenie, że wychowanie i nauczanie są także sztuką, wymagają bowiem szczególnego rodzaju wrażliwości, innowacyjności działań i twórczego zaangażowania" (Śliwerski 2010, s. 125). Obie formy pomocowe (wspomaganie i wspieranie) są obecne w działaniach szkoły na każdym etapie edukacyjnym. Rozwiązania systemowe zapewniają uczniom specjalistyczną pomoc w ramach dodatko- 
wych zajęć $c^{1}$ jednocześnie wspomaganie i wspieranie winno być stałym elementem oddziaływań pedagogicznych, zarówno podczas lekcji, jak i innych zajęć pozalekcyjnych. Powoduje to istotną zmianę w postrzeganiu pomocy wyłącznie jako interwencji w stronę platformy działań profilaktycznych, wyprzedzających.

Porównanie wychowania, $\mathrm{w}$ tym pomocy, do sztuki wiąże się z innym postrzeganiem jej realizatorów, którzy przestają być biernymi wykonawcami dyrektyw, zaleceń i przepisów, a stają się osobami otwartymi, kreatywnymi, działającymi i zmieniającymi praktykę. W swoich działaniach kierują się refleksyjnością, która jest zdolnością jednostki do refleksji (Czerepaniak-Walczak 1997), głębszego namysłu, rodzącego się z wątpliwości i niepewności. Refleksyjność definiowana jest jako „analizowanie przeżytych doświadczeń oraz włączanie nowej wiedzy lub nowych informacji do codziennego działania" (Kargulowa 2006, s. 208). Jest to rodzaj spojrzenia na siebie, na innych i krytyczna ocena swojej pracy, której towarzyszą pytania: jaki jestem? czy to, co robię, jest dobre? po co to robię?. Jakkolwiek wiedza i rutyna nie ograniczają działań, to jednak refleksyjność pomaga w kreowaniu własnego profesjonalizmu przy rozumieniu rutynowości jako działań odtwórczych, podporządkowanych dyrektywom i opartych na powtarzaniu wyuczonych czynności. „Profesjonalizm w zawodzie nauczyciela - jak zauważyła Henryka Kwiatkowska - to nie fachowość na wzór zawodów technicznych, sprawnościowych, realizowanych przez aplikację reguł technicznych, technologicznych w działaniu praktycznym. To spełnienie wysokich standardów: poznawczych, działaniowych i etycznych" (Kwiatkowska 2008, s. 167). Profesjonalni praktycy w swojej pracy zawodowej spotykają się ze złożonymi problemami, w rozwiązaniu których nie mogą polegać na wiedzy i algorytmach postępowania w określonej sytuacji, ale na „zdolności do refleksji przed podjęciem działania” (Rylke 2007, s. 37). Często muszą oni na bieżąco definiować problemy i organizować działania pomocowe.

W procesie udzielania pomocy szczególnie wartościowa jest refleksja nad metaumiejętnościami, takimi jak: komunikacja, zdolność rozumienia empatycznego, zdolność oceniania, motywowanie do aktywności i dzielenie się doświadczeniami. Idea refleksyjności kreuje postawę refleksyjnego praktyka, który to termin został w prowadzony w latach 80. ubiegłego wieku (Schön 1987).

Kim jest refleksyjny praktyk? Jest to osoba, która „ma zdolność do inteligentnego działania w dynamicznie zmieniających się, niedostatecznie rozpoznawalnych i niepowtarzalnych sytuacjach" (Gołębniak 2009, s. 48). Małgorzata Taraszkiewicz zauważyła, że refleksyjny praktyk to „osoba, która myśli o tym, co aktualnie robi”

1 Rozporządzenie MEN z 30 kwietnia 2013 r. w sprawie zasad udzielania i organizacji pomocy psychologiczno-pedagogicznej w publicznych przedszkolach, szkołach i placówkach (Dz. U z 2013 r., poz. 532). 
(Taraszkiewicz 1998, s. 19), jakkolwiek refleksja odnosi się zarówno do działań aktualnych, jak i przeszłych, które analizujemy z perspektywy czasowej, stąd refleksja „w” działaniu, refleksja „nad działaniem” i refleksja „o" działaniu. Owa refleksja pozwala na rozumienie sytuacji i korzystanie $\mathrm{z}$ informacji zwrotnych w celu zmiany czy modyfikacji swojego zachowania i strategii działania. O refleksyjności w pedagogice pisali m.in.: Donald Schön (1987), Ellen Langer (1993), Hanna Rylke (1997), Maria Czerepaniak-Walczak (1997), Roman Leppert (1998), Małgorzata Taraszkiewicz (1998), Dorota Gołębniak (2002, 2009), Alicja Kargulowa (2006), Henryka Kwiatkowska (2008), Joanna Kłodkowska (2010), Bogusław Śliwierski (2010).

Refleksyjna praktyka winna być udziałem nauczyciela wspierającego, ale czy jest ona obecna w jego działaniach?

\section{WOKÓ£ POMOCY PSYCHOLOGICZNO-PEDAGOGICZNEJ}

Pomoc psychologiczno-pedagogiczna jest ważnym elementem działań każdej szkoły, a za jej organizację odpowiada dyrektor. Celem działań pomocowych jest wyrównywanie szans edukacyjnych uczniów i wspieranie funkcji wychowawczej rodziców. Zakres i rodzaj pomocy są wyznaczane bieżącymi potrzebami uczniów, możliwościami szkoły w rozumieniu warsztatu pracy pedagogicznej, jak również poziomem kompetencji i postaw nauczycieli. Współczesna szkoła jest przestrzenią dla wielu praktyk pomocowych, ale ich jakość i odbiór wciąż są przedmiotem dyskusji. Systemowe rozwiązania kreują jej wizerunek jako placówki, której celem jest zaopiekowanie się każdym uczniem, chociaż faktyczne działania spotykają się często z oporem, sprzeciwem adresatów, czyli osób potrzebujących wsparcia specjalistycznego.

Zmieniające się projekty i modele wspomagania uczniów (Rozporządzenie MEN 2010, 2013) zmierzają do tego, aby pomoc ta była udzielana jak najwcześniej i jak najbliżej ucznia. Jak czytamy w materiałach MEN z 2009 roku, „,rozpoznanie potrzeb ucznia ma dotyczyć zarówno trudności w uczeniu się, jak i jego indywidualnych predyspozycji oraz uzdolnień” (Rozporządzenie MEN 2010, s. 5). Informacje uzyskane z Systemu Informacji Oświatowej (SIO) podtrzymują tezę o konieczności organizowania specjalistycznej pomocy z uwagi na wzrastającą liczbę uczniów ze specjalnymi potrzebami edukacyjnymi² (Rozporządzenie MEN 2010).

Treści aktualnego Rozporządzenia MEN z 30 kwietnia 2013 r. w sprawie zasad udzielania i organizacji pomocy psychologiczno-pedagogicznej w publicznych

2 Termin „specjalne potrzeby edukacyjne” określa szeroki zakres zjawisk, obejmuje zarówno potrzeby dzieci upośledzonych umysłowo, jak i dzieci ze specyficznymi trudnościami w uczeniu się oraz wybitnie uzdolnione (zob. Karcz-Taranowicz 2015, s. 131). 
przedszkolach, szkołach i placówkach (Dz.U. 2013. Poz. 532) określają zakres i formy tej pomocy. Czytamy w nim, iż „pomoc psychologiczno-pedagogiczna udzielana uczniowi w przedszkolu, szkole i placówce polega na rozpoznawaniu i zaspokajaniu indywidualnych potrzeb rozwojowych i edukacyjnych ucznia oraz rozpoznawaniu indywidualnych możliwości psychofizycznych ucznia” (Rozporządzenie MEN 2013). Dla zobrazowania skali problemu w kontekście organizacji form pomocy psychologiczno-pedagogicznej posłużono się badaniami prowadzonymi przez pracowników Uniwersytetu Jana Kochanowskiego w Kielcach, które zostały opublikowane w roku 2013 (Bidziński, Giermakowska, Ozga, Rutkowski 2013). Jak wynika z nich, najczęściej realizowaną formą pomocy w szkole są zajęcia korekcyjno-kompensacyjne i logopedyczne, zwłaszcza w szkołach podstawowych i przedszkolach, a najrzadziej zajęcia socjoterapeutyczne (najniższy wskaźnik uzyskany w częstości organizowania form pomocowych) (Bidziński, Giermakowska, Ozga, Rutkowski 2013, s. 197-198). Pomoc psychologiczno-pedagogiczna jest też zdecydowanie częściej organizowana w szkołach miejskich, aniżeli wiejskich (Bidziński, Giermakowska, Ozga, Rutkowski 2013, s. 200-201). Są to ilościowe parametry udzielania pomocy, które generują pytania o jej jakość i przebieg, co wymaga pogłębienia analiz w nurcie orientacji jakościowych.

\section{PRAKTYKA UDZIELANIA POMOCY - PRZESTRZEŃ DLA RUTYNY I MIEJSCE NA REFLEKSJĘ}

Proces wspomagania rozwoju uczniów realizowany w szkole, podobnie jak inne działania dydaktyczne, jest „nieadekwatny do płynnej nowoczesności” (Bałachowicz 2015, s. 41). Ma to złożone i wielorakie uwarunkowania związane m.in. ze zmianą postrzegania dziecka, innym widzeniem roli szkoły, kompetencjami nauczyciela czy oczekiwaniami rodziców. Obszar kompetencji pomocowych nauczycieli jest przedmiotem wielu badań, które wskazują na niski lub przeciętny stan posiadanej przez nich wiedzy i umiejętności w zakresie realizacji form pomocowych, terapeutycznych (Bartnikowska, Wójcik 2004; Garlej-Drzewiecka 2004; Włoch, Włoch 2009, 2015; Skałbania 2010; Buchnat 2014; Lewandowska-Kidoń, Witek 2014; Miecznik-Warda 2015). Ta niska samoocena nauczycieli ma odzwierciedlenie w bieżących działaniach pomocowych, które są nieskuteczne i nielubiane przez uczniów.

Najczęściej proces udzielania pomocy jest inicjowany i organizowany przez nauczyciela, który postępuje według określonych algorytmów, wyznaczonych procedur. Przejawem refleksyjnego myślenia nauczyciela jest zastanowienie się nad swoją koncepcją postrzegania ucznia. Przyjęcie koncepcji oświeceniowej 
projektuje u nauczyciela postawę mentora, wybór koncepcji romantycznej wiąże się z traktowaniem dziecka jako naiwnej istoty, w koncepcji pozytywistycznej nauczyciel naucza, informuje, przekazuje, w koncepcji humanistycznej zaś zaprasza ucznia do refleksji i wspólnych działań (Taraszkiewicz 1998, s. 22-23). Już $\mathrm{w}$ pierwszym etapie procesu pomocowego istotne jest uświadomienie sobie celów, dokonanie refleksji nad możliwościami własnymi oraz podopiecznego, analiza zasobów z uwzględnieniem kontekstu środowiskowego, jak również analiza wyników diagnozy. Tu winny pojawić się następujące pytania: po co mam to robić? jak mam to robić? jaki cel chcę osiągnąć? jakimi możliwościami dysponuję?. Jeżeli nauczyciel nie dokonuje takiej refleksji, a stosuje kryterium negatywnego wartościowania ucznia jako efekt przeniesienia, zaczyna działać bezrefleksyjnie. Język jako narzędzie komunikacji społecznej też może być wyrazem podejścia refleksyjnego versus podejścia technologicznego, które czyni pomoc rodzajem spotkania osobowego lub bezpodmiotowej usługi. Rutynowe praktyki, język dyrektywny budują dystans, do którego pokonania potrzebna jest refleksja ${ }^{3} \mathrm{z}$ kluczowym pytaniem: dlaczego?

Refleksja w działaniu pomocowym polega na ciągłej analizie przebiegu relacji uczeń-nauczyciel w kontekście prowadzonej rozmowy (dlaczego on mi to mówi? co chce mi przez to powiedzieć? czy to, o czym mówi, ma jakieś znaczenie?), jak też sposobu realizacji zadań (czy to nie jest dla niego zbyt trudne? dlaczego tak to wykonał? dlaczego sobie z tym nie poradził?). Konsekwencją stawianych pytań jest pozyskiwanie informacji o uczniu i o sobie, rozwijanie krytycznego myślenia i namysłu nad praktyką. Pozwalają one zrozumieć zaistniałą sytuację, a nie tylko jej ocenę i to często negatywną. Werbalizacja jako działanie refleksyjne łączy się z innymi działaniami wpisanymi w repertuar refleksyjnego praktyka, takimi jak: samoocena (zachęcanie uczniów do dokonywania oceny swojej osoby), ocenianie innych, dyskusje problemowe czy metoda dialogowa, które ujawniają indywidualne cele, problemy, zapraszają do rozmowy i uczą oceniania oraz wywołują refleksję. Jak zauważył Jerome Bruner, relacja z dzieckiem pozbawiona dialogu jest poważną blokadą w rozwoju. Paradoksy blokady rozwoju ucznia w sytuacji zajęć wspierających są dostrzegane w wielu sytuacjach terapeutycznych, w których nauczyciel wierny własnemu doświadczeniu i rutynie reżyseruje przebieg spotkania, planuje jego szczegóły, tym samym zamyka przestrzeń dla aktywności, kreatywności wspomaganego. Stosowanie przez nauczycieli gotowych scenariuszy zajęć, kart pracy jest równoznaczne z pozbawieniem ucznia możliwości spontanicznego, kreatywnego rozwoju, jest próbą wpisania

3 „[C]zynność umysłu polegająca na ujmowaniu lub tylko uświadamianiu własnych aktów »w tym samej refleksji « w aspekcie ich istnienia, zawartości, struktury i przebiegu" (Encyklopedia pedagogiczna XXI wieku 2006, s. 69). 
go w scenariusz jednego autora. Schematyczne zachowanie nauczyciela skupionego na procedurach, a nie na osobie powoduje, iż osoba wspomagana (uczeń) odbiera pomoc, dodatkowe zajęcia jako formę przymusu, sytuację wymuszoną, której nie akceptuje.

Brak refleksji nad własną postawą, zwłaszcza nauczyciela nadopiekuńczego, może być powodem kształtowania się u ucznia syndromu „wyuczonej bezradności” (termin wprowadzony przez Martina Seligmana) w miejsce kształtowania jego zaradności i niezależności. Uczeń wyręczany w działaniu, wobec którego nie stosuje się wzmocnień pozytywnych, traci wiarę w swoje umiejętności i możliwą zmianę, co zawiera się w słowach: „nie umiem”, „nie potrafię tego zrobic”, lub wycofuje się z sytuacji zadaniowej. Refleksja nad praktyką dokonywana z perspektywy czasu jest zdobywaniem doświadczeń, poszukiwaniem nowych rozwiązań, oceną już stosowanych, co w efekcie rozwija kreatywność, aktywność i doskonali profesjonalizm. Refleksyjny nauczyciel organizuje pomoc aktywną, pozwala na działania, osobiste oceny i namysł, co sam też praktykuje. Jego głównym zadaniem jest więc uaktywnienie potencjału wychowanków. Refleksyjny praktyk nie ufa gotowym rozwiązaniom, analizuje i krytycznie odnosi się do praktyki, modyfikuje program pomocy, wprowadza nowe formy pracy, odbiera i analizuje informacje zwrotne od ucznia.

Praktyczność pedagogiki uzasadnia zapotrzebowanie na refleksyjnych praktyków, nauczycieli, którzy „swoją wiedzę budują w toku sytuacyjnych rozumień, generowanych w wyniku refleksji w działaniu i nad działaniem" (Kłodkowska 2010, s. 203). Refleksyjny nauczyciel rozważa, zastanawia się, analizuje, czyli „myśli jak pedagog" (Śliwerski 2010). Akceptuje sytuację, w której trudności, niedoskonałości, błędy mogą być źródłem refleksji, elementem rozwoju, a nie jedynie przyczyną negatywnych emocji prowadzących do jeszcze większego usztywnienia działań. Analiza własnej praktyki polega na jej ocenie i interwencji w nią, co pozwala na zmiany w kierunku pozytywnym. Stagnacja, zrutynizowanie działań prowadzą niejednokrotnie do wypalenia zawodowego nauczyciela.

Podejście wspomagające musi być refleksyjne, aby było skuteczne i podmiotowe, bo wtedy pozwala na lepsze zrozumienie indywidualnych problemów ucznia, zastanowienie się nad ich przyczyną, ale też daje przestrzeń dla osobistych przemyśleń i swobodnych działań kreatywnych. Rozumienie, otwartość, elastyczność i odpowiedzialność to kluczowe cechy refleksyjnego praktyka, które mają stanowić ważny element kompetencji doradczych, pomocowych, terapeutycznych nauczyciela, którego powinnością jest nie tylko podejmowanie dyrektywnych działań, ale rozumienie faktów pedagogicznych i przekształcanie bieżącej rzeczywistości. 
Refleksyjność jest początkiem udzielania atrakcyjnej i aktywnej pomocy, zrywa ze schematyzmem stosowanych rozwiązań, uruchamia postawę aktywnego badacza, który poznaje, odkrywa, wdraża i monitoruje działania przez wnikliwą obserwację i korzystanie z informacji zwrotnych (zachowania werbalne i niewerbalne ucznia).

W literaturze opracowano listę metod wykorzystywanych przez refleksyjnych praktyków w ich codziennej pracy (Perkowska-Klejman 2012, s. 106-114). Wśród nich można odnaleźć te, które nauczyciel może wykorzystać w swojej działalności pomocowej. Należą do nich: uczenie się przez działanie, krytyczna analiza zdarzeń, superwizja, opieka mentora, nieformalna dokumentacja pracy (zapis własnych działań i przemyśleń). Wszystkie one pozwalają na bardziej wnikliwe spojrzenie na własną działalność pedagogiczną i terapeutyczną, również przez skorzystanie ze wsparcia osoby mającej niekiedy większe doświadczenie.

\section{PODSUMOWANIE}

"Refleksja”, „refleksyjność” i „refleksyjny praktyk” to pojęcia typowe dla nowej koncepcji profesjonalizmu, która jest szczególnie wartościowa w obszarze pomocowym i poradniczym. Mimo kontrowersyjnych opinii co do posiadania przez nauczyciela refleksyjności, jest ona cechą pomagającą i ułatwiającą działania praktyczne. Przesłaniem do kształtowania refleksyjności nauczycieli mogą być następujące słowa: „Rozwiązanie problemu nie polega na lepiej dostosowanych klasach szkolnych, ich wyposażeniu, systemie podziału na grupy, nowych technikach i metodach, choć one też mają swój wpływ. Rozwiązanie to leży w Tobie" (Whitmore 1994, za: Taraszkiewicz 1998, s. 20).

\section{LITERATURA}

Bałachowicz J. (2015). Od indywidualizacji do personalizacji. Nowe obszary zadań i kompetencji nauczyciela wczesnej edukacji. W: E. Smak, A. Włoch, M. Grabiec (red.). Diagnozowanie i terapia uczniów ze specjalnymi potrzebami edukacyjnymi. Opole, s. 33-51.

Bartnikowska U., Wójcik M. (2004). Zaniedbania $w$ aspekcie triady: szkoła-rodzice-dziecko $w$ kształceniu integracyjnym i masowym dzieci z wada stuchu. W: Z. Gajdzica, D. Osik-Chudowolska (red.). Wątki zaniedbane, zaniechane, nieobecne $w$ procesie edukacji $i$ wsparcia społecznego osób niepełnosprawnych. Lublin, s. 287-295. 
Bidziński K., Giermakowska A., Ozga A., Rutkowski M. (2013). Nauczyciele województwa świętokrzyskiego wobec zadań związanych $z$ realizacja specjalnych potrzeb edukacyjnych uczniów. Kielce.

Bruner J. (2010). Kultura edukacji. Warszawa.

Buchnat M. (2014). Kompetencje i oczekiwania nauczyciela do pracy $z$ dzieckiem ze specjalnymi potrzebami edukacyjnymi. Komunikat z badań. „Studia Edukacyjne" 31, s. 177-194.

Czerepaniak-Walczak M. (1997). Aspekty i źródła profesjonalnej refleksji nauczyciela. Torun.

Encyklopedia pedagogiczna XXI wieku. (2006). Warszawa.

Garlej-Drzewiecka E. (2004). Pedeutologiczny kontekst myślenia o nauczycielu wiodącym i wspierającym. W: C. Kosakowski, A. Krause (red.). Dyskursy pedagogiki specjalnej. Rehabilitacja, opieka i edukacja specjalna w perspektywie zmian. T. 3. Olsztyn.

Gołębniak B.D. (2002). Nabywanie kompetencji do refleksyjnego nauczania. W: B.D. Gołębniak (red.). Uczenie się metoda projektów. Warszawa, s. 10-28.

Gołębniak B.D. (2009). Aplikacje konstruktywizmu do poradoznawstwa. Inspiracje pedeutologiczne. W: A. Kargulowa (red.). Poradoznawstwo - kontynuacja dyskursu, Warszawa, s. 36-61.

Karcz-Taranowicz E. (2015). Zadania dyrektora szkoły w zakresie opieki nad uczniem ze specjalnymi potrzebami edukacyjnymi. W: E. Smak, A. Włoch, M. Grabiec (red.). Diagnozowanie i terapia uczniów ze specjalnymi potrzebami edukacyjnymi. Opole, s. 129-137.

Kargulowa A. (2006). O teorii i praktyce poradnictwa. Podręcznik akademicki. Warszawa.

Kłodkowska J. (2010). Aplikacja konstruktywizmu do praktyki poradnictwa. „Edukacja Dorosłych. Poradnictwo dla dorosłych - refleksje, badania, praktyka" 1 (62), s. 199-213.

Kwiatkowska H. (2008). Pedeutologia. Warszawa.

Langer E. (1993). Problemy uświadamiania. Konsekwencje refleksyjności i bezrefleksyjności. W: T. Maruszewski (red.). Poznanie. Afekt. Zachowanie. Warszawa, s. 137-179.

Leppert R. (1998). Nauczyciel jako adaptacyjny technik, refleksyjny praktyk, transformatywny intelektualista. W: W. Prokopiuk (red.). Rozwój nauczyciela w okresie transformacji. Białystok, s. 219-226.

Lewandowska-Kidoń T., Witek A. (2014). Gotowość nauczycielek edukacji wczesnoszkolnej do pracy z dzieckiem przewlekle chorym. W: W. Żłobicki (red.). Transgresje w edukacji. T. 1. Kraków, s. 253-262. 
Miecznik-Warda J. (2015). Diagnoza i wspomaganie dzieci z zaburzeniami percepcji wzrokowej. W: E. Smak, A. Włoch, M. Grabiec (red.). Diagnozowanie i terapia uczniów ze specjalnymi potrzebami edukacyjnymi. Opole, s. 175-187.

Obuchowska I. (1997). Wspomaganie rozwoju emocjonalnego: refleksje i propozycje. W: B. Kaja (red.). Wspomaganie rozwoju. Psychostymulacja, psychokorekcja. Bydgoszcz, s. 35-47.

Perkowska-Klejman A. (2012). Refleksyjna praktyka w pracy pedagoga szkolnego. „Ruch Pedagogiczny” 3, s. 101-116.

Podniesienie efektywności kształcenia uczniów ze specjalnymi potrzebami edukacyjnymi. Materiały szkoleniowe. (2010). Część I. Warszawa, MEN.

Rozporządzenie MEN z dnia 30 kwietnia 2013 r. w sprawie zasad udzielania i organizacji pomocy psychologiczno-pedagogicznej w publicznych przedszkolach, szkołach i placówkach. Dz.U. 2013. Poz. 532.

Rylke H. (1997). Refleksyjny praktyk - nowa tożsamość nauczyciela. Warszawa.

Rylke H. (2007). „Wielka Improwizacja” - o działaniu refleksyjnych praktyków. „Psychologia w Szkole" 2 (14), s. 37-42.

Schön D. (1987). The Reflective Practitioner. How professionals think in action. New York.

Skałbania B. (2010). Szkolne formy wsparcia i pomocy uczniom ze specyficznymi trudnościami w nauce w świetle badań własnych. W: B. Witkowska, K. Bidziński, P. Kurtek (red.). Dzieci i młodzież ze specjalnymi potrzebami edukacyjnymi $w$ realizacji zadań rozwojowych. Kielce, s. 273-285.

Śliwerski B. (2010). Myśleć jak pedagog. Sopot.

Taraszkiewicz M. (1998). Jak uczyć lepiej? Czyli refleksyjny praktyk $w$ działaniu. Warszawa.

Whitmore D. (1994). Radość uczenia się. Zastosowanie psychosyntezy w wychowaniu. Praktyczny poradnik dla nauczycieli i rodziców. Warszawa.

Włoch A., Włoch S. (2015). Uczeń ze specjalnymi potrzebami edukacyjnymi. Diagnoza-działanie-efekty. W: E. Smak, A. Włoch, M. Grabiec (red.). Diagnozowanie i terapia uczniów ze specjalnymi potrzebami edukacyjnymi. Opole, s. 165-175.

Włoch S., Włoch A. (2009). Diagnoza całościowa w edukacji przedszkolnej i wczesnoszkolnej. Warszawa. 


\title{
PSYCHOLOGICAL AND PEDAGOGICAL ASSISTANCE AT SCHOOL \\ - BETWEEN ROUTINE AND REFLECTIVE PRACTICE
}

\begin{abstract}
This article aims to highlight the reflectance as an important element of pedagogical activities, as well as the need for education of reflective practitioners, in accordance with the education law of 2012 on education standards preparing for teaching profession. Thematic considerations apply to the educational process and they are especially targeted at the area of psychological and pedagogical assistance because of its fairly marginal treatment in relation to the numerous and multi-scoped analysis of the functioning of school, especially in terms of its teaching activities.
\end{abstract}

Keywords: psychological and pedagogical assistance, reflective practitioner, competences of teachers 